\title{
AN ANALYSIS OF PROSPECTIVE PRIMARY SCHOOL TEACHERS' INTERCULTURAL SENSITIVITY IN TERMS OF DIFFERENT CULTURAL VARIABLES
}

\author{
SINIF ÖĞRETMENİ ADAYLARININ KÜLTÜRLERARASI DUYARLILIK \\ DÜZEYLERINIIN FARKLI KÜLTÜREL DEĞIŞKENLER AÇISINDAN INCELENMESİ
}

\author{
Hanifi ŞEKERC I ${ }^{1}$ - M. Cihangir DOĞAN ${ }^{2}$
}

\begin{abstract}
This study aims to analyse prospective primary school teachers' levels of intercultural sensitivity in Turkey according to the variables of national cultural differences and experiencing the differences at national level socially. Causal-comparative research model and Simple random sampling method were used in the study. 387 undergraduate students attending the primary School Teaching Departments of Ziya Gökalp Faculty of Education of Dicle University and Atatürk Educational Faculty of Marmara University were included in this research. The data was collected by the Intercultural Sensitivity Scale (ISS). Descriptive statistics were used in the analysis of the data independent sample t-test and one-way ANOVA. As a result, it was found that prospective primary school teachers are at satisfactory levels in terms of intercultural sensitivity. Additionally, intercultural sensitivity levels of prospective primary school teachers using two or more languages in communication with their family members or relatives were significantly higher than those using one language.
\end{abstract}

Keywords: Intercultural sensitivity, intercultural awareness, Cultural differences.

\section{$\ddot{O} \mathbf{z}$}

$\mathrm{Bu}$ çalışmada sınıf öğretimeni adaylarının kültürler arası duyarlılık düzeylerinin ulusal kültürel farklılıklar ve bu farklılıkları ulusal düzeyde deneyimleme değişkenlerine göre incelemek amaçlanmaktadır. Araş̧ırmada nedensel karşılaştırma araştırma modeli ile basit rasgele örneklem tekniği kullanılmıştır. Araştırmaya Dicle Üniversitesi Ziya Gökalp Eğitim Fakültesi ile Marmara Üniversitesi Atatürk Eğitim Fakültesinde öğrenim gören 387 sinıf öğretmeni adayı katılmıştır. Çalışmada veriler kültürler arası duyarlılık ölçeği ile toplanmıştır. Verilerin analizinde bağımsız gruplar t- testi ve one-way anova testleri kullanılmıştır. Araştırma bulgularına göre sınıf öğretmeni adaylarının kültürler arası duyarlılık seviyesi yeterli düzeydedir. Bunun yanında akrabaları veya aile üyeleri ile iletişiminde iki veya daha fazla dil kullanan sınıf öğretmeni adaylarının kültürler arası duyarlılık düzeyi tek dil kullananlara göre anlamlı olarak daha yüksektir.

Anahtar Kelimler: Kültürlerarası duyarlılık, kültürlerarası farkındalık, kültürel farklılıklar.

\footnotetext{
${ }^{1}$ Arş.Gör.Dr., Dicle Üniversitesi Ziyagökalp Eğitim Fakültesi. İlköğretim Bölümü, hnfskrc @ gmail.com, Orcid:0000-0002-1280-3228

${ }^{2}$ Prof.Dr., Marmara Üniversitesi Atatürk Eğitim Fakültesi, mcdogan@ marmara.edu.tr, Orcid:0000-0003-14737866
} 


\section{Introduction}

One of the most important concepts facing us today- when people with differing cultures try to use all instruments of intercultural communication in the most effective and efficient way- is intercultural sensitivity, which has the power to determine the quality of intercultural communication process. A review of relevant literature demonstrates that a great number of studies concerning the power of intercultural sensitivity are available. Yet, a considerable number of those studies (Altshuler, Sussman, and Kachur 2003; Anderson et al. 2006; Clarke et al. 2009; Del Villar 2010; Fabregas-Janeiro, Kelsey, and Robinson 2011; Fuller 2007; Pedersen 2010; Straffon 2003; Üstün 2011; Williams 2005) consider the issue in the context of globalization and focus on cultural differences only at international level. However, intercultural sensitivity is a quality which is not only international but also needs to be gained nationally welcoming in its body diverse cultural properties (Anderson et al. 2006). One of the countries where intercultural sensitivity has gained importance at national level from the aspect of cultural differences is Turkey.

Turkey is a country where people with cultural, ethnical and belief differences live (Şahin \& Ekici, 2019). Despite this, there are no academic studies reporting the quantity of people representing the diverse cultural groups. The data coming from the report on Turkey prepared by International Minority Rights Group [Uluslararası Azınlık Hakları Grubu] (2007) also confirms this. On the other hand, the proportion of the sub-cultural groups in Turkey is approximately $24 \%$ according to the report prepared by KONDA (2006)- a research company. According to the findings obtained by the research company, the most crowded group representing the sub-culture in Turkey is the Kurds- Zazas in terms of ethnicity. They represent $15.7 \%$ of Turkey's population. The proportion of Arab citizens in the total population is $0.7 \%$. The ratio of groups representing the sub-culture in terms of belief in the total population is about $8 \%$. The biggest group representing the sub-culture in belief is the Alewis. They constitute $5.02 \%$ of the population in Turkey. In the same vein, approximately $2 \%$ of the population in Turkey is composed of non-Muslims. This data exhibits the rich demographic structure of Turkey containing diverse cultural properties. This situation shows that people with culturally different properties in Turkey can easily communicate in many spheres of life. It may be thought that one of those spheres can be the field of educational activities. The reason for this is that people with different cultural properties can come together due to the mobility of sometimes teachers and sometimes students, and thus they can have interaction. On considering the issue from the aspect of teachers' mobility, it is clear that one of the branches of teaching having the most mobility into regions where people with different cultural properties live is primary school teaching.

According to data coming from Council of Higher Education [Yüksek Öğretim Kurulu/YÖK] (2016), prospective primary school teachers are offered pre-service training in 74 educational faculties located in seven geographical regions of Turkey. While 18 of the educational faculties are under the roof of universities located in the Eastern and Southeastern regions, the remaining 56 faculties are in the universities in the other regions. This situation indicates that it is possible for anybody to receive undergraduate education in primary school teaching in almost every part of Turkey and that prospective teachers do not have to go to a different region or experience a different culture to receive the education. However, regardless of the university graduation or the region where a considerable part of life has been spent, the majority of the prospective primary school teachers are employed in the Eastern and the South eastern regions of Turkey, which are different from all other regions of Turkey in ethnicity, mother tongue and belief (KONDA 2006). This causes primary school teachers to enter into the process of communication with students and parents having different cultural properties. So that the process of communication can be healthy, primary school 
teachers need to have intercultural communication skills (Perry and Southwell 2011; Williams 2005).

Intercultural communication skill is defined as communication between at least two individuals with differing cultural backgrounds by using verbal or non-verbal instruments of communication (Neuliep 2006). Intercultural communication skills contain a covert invitation and desire to start interaction between different cultures and identities on the foundation of "recognition, understanding, respect and tolerance" (Bekiroğlu and Balc1 2014). Intercultural communication skill has three dimensions: cognitive, behavioral and affective. Intercultural awareness- which is the cognitive dimension of the skill- means understanding how cultural manners and traditions influence thoughts and behaviors. Intercultural competence, which is the behavioral dimension, means behaving effectively in intercultural interaction and being able to solve the problems stemming from cultural differences. Intercultural sensitivity, which is the affective dimension, refers to a developmental process in which individuals develop cognitive, affective and behavioral efficacies (Baños 2006; Chen and Starosta 1998-9; Peng 2006).

According to Developmental Model approach, intercultural sensitivity basically includes two stages- namely, ethnocentrism and ethnorelativism (Bennett 1986). A person at the stage of ethnocentrism perceives his/her culture as the center of reality and thinks that his/her beliefs and behaviors in the basic process of socialization are unquestionable. An individual at the stage of ethnorelativism, on the other hand, is aware of the fact that his/her beliefs and behaviors constitute only a part of reality (Bennett and Bennett 2004; Bennett 2004). Therefore, he/she is open to facing differing cultural experiences so as to acquire diverse perspectives of reality.

As the levels of intercultural sensitivity rise, individuals tend to be less ethnocentric (Chen 2010). Such individuals display the characteristics of interaction engagement, respect of cultural differences, interaction confidence, interaction enjoyment and interaction attentiveness- which Chen and Starosta (2000) regard as the indicators of intercultural sensitivity- more in order to reach differing perspectives of reality. Thus, researches and studies published indicate that individuals with high levels of intercultural sensitivity can be more effective while working in different cultural environments (Bhawuk and Brislin 1992) and that their care in serving, their interpersonal skills and their job and social satisfaction will be higher (Sizoo et al. 2005).

The above mentioned benefits of intercultural sensitivity in career gain importance while working in educational environments. It means that primary school teachers, for whom working especially in the Eastern and south eastern regions of Turkey is a cultural change, need to adjust into the unusual culture when they work in those regions. This in turn means that they need to have more sensitivity in intercultural differences (Chen 1997). Otherwise, primary school teachers may not be adequately helpful to students going to schools in those regions and achieving less success in nationwide examinations than the students in other regions in terms of uncovering their potentials (Yuen and Grossman 2009). Besides, teachers with low levels of intercultural sensitivity may not satisfy the social, personal and cultural demands of students receiving education in those regions and thus they may deeply hurt individuals (Rengi and Polat 2014). Moreover, the fact that curricula do not include any gains in relation to the cultural properties of the groups representing the sub-cultures (Cirlk 2008) and that the teacher training programs and institutions have great lacks in multicultural education (Polat and Kıliç 2013) can further deepen the problems. Thus, it was shown in research that teachers who had not taken any courses in multicultural education, who had low levels of intercultural sensitivity, who could not evaluate the reflections of cultural differences into educational environments and who were not competent in this respect could be 
incompetent in meeting the educational needs of students having culturally different properties (Gay 2002; Başbay 2014). In this context, it is considered important to analyze the intercultural sensitivity levels of prospective primary school teachers who are still at university in terms of cultural variables, to discuss the issue within the framework of scientific literature if there are obstacles in front of them hindering their achievement in regions with diverse cultural properties, and to make the necessary recommendations.

Studies placing primary school teachers' and prospective primary school teachers' intercultural sensitivity can be found in the literature. One such study performed by Spinthourakis, Karatzia-Stavlioti, and Roussakis (2009) found that prospective Greek primary school teachers had high levels of intercultural sensitivity. The study analyzed prospective primary school teachers' intercultural sensitivity levels in terms of gender, department of study, grade level and perceptions of efficacy in intercultural education. Üstün (2011)analyzing the level of intercultural sensitivity in terms of gender, department of study, grade levels, the type of high school prospective teachers had graduated from, geographical regions, place of settlement, whether or not prospective teachers had been abroad, and whether or not they had any friends living in other countries or in different cultures- found in a similar way that prospective primary school teachers had high levels of intercultural sensitivity. Rengi and Polat (2014) demonstrated that primary school teachers as well as prospective primary school teachers had high levels of intercultural sensitivity. The researchers analyzed primary school teachers' intercultural sensitivity from the aspect of gender, seniority in teaching, and grade level of teaching. Bayles (2009), in contrast to the above mentioned studies, found that primary school teachers teaching in the rural areas of Texas were ethnocentric - in other words, they were not at the desired level- in terms of intercultural sensitivity. Bayles analyzed primary school teachers' levels of intercultural sensitivity in terms of gender, age, level of education, living in bicultural environments, working in schools, experience in working with children of different ethnic groups and experience in working in bilingual classes. As is clear from all these studies, pre-service and in-service teachers' levels of intercultural sensitivity were generally analyzed according to demographic variables, occupational variables, and according to experiencing cultural differences in educational environments and experiencing cultural differences at international level. None of the studies focused on cultural differences at the national level or on experiencing the cultural differences at international level socially. Therefore, this study aims to analyze prospective primary school teachers' levels of intercultural sensitivity in Turkey according to the variables of national cultural differences and experiencing the differences at national level socially. Thus, answers are sought to the following questions:

- At what levels are prospective primary school teachers in terms of intercultural sensitivity?

- Do the intercultural sensitivity levels of primary school teacher candidates differ according to the ethnic origin variable?

- Do the intercultural sensitivity levels of primary school teacher candidates differ according to the native language variable?

- Do the intercultural sensitivity levels of primary school teacher candidates differ according to the belief variable?

- Do the intercultural sensitivity levels of primary school teacher candidates differ according to the variable of the number of languages used in communication in their family? 
- Do the intercultural sensitivity levels of primary school teacher candidates differ according to the variable of the settlement where most of their life is spent?

- Do the intercultural sensitivity levels of primary school teacher candidates differ according to lived in a place with different cultural properties in Turkey?

- Do the intercultural sensitivity levels of primary school teacher candidates differ according to the variable of having a close friend of Turkish nationality who is culturally different?

\section{Methods}

\section{Research model}

This study employs a survey model to investigate prospective primary school teachers' level of intercultural sensitivity on average. A survey model is a research approach aiming to describe a situation which existed in the past or which exists at present as it is (Karasar 2012). A causal comparative research model is used in this study to find according to which variables prospective teachers' levels of intercultural sensitivity differ significantly. Causal comparative research model is a model aiming to find what variables cause differences between groups of people and the results of the differences without any interference in conditions and participants (Büyüköztürk et al. 2013).

\section{Participants}

387 undergraduate students attending the primary School Teaching Departments of Ziya Gökalp Faculty of Education, Dicle University and Atatürk Faculty of Education, Marmara University were included in the study. The distribution of the participants is shown in Table 1.

Table 1. Demographic information on the prospective primary school teachers included in the study

\begin{tabular}{llcc}
\hline Variables & Sub-Variables & $\mathbf{f}$ & $\mathbf{\%}$ \\
\hline & Kurd- Zaza & 251 & 65.5 \\
Ethnicity & Turk & 114 & 29.8 \\
& Other & 18 & 4.7 \\
\hline & Kurdish- Zazaish & 170 & 43.9 \\
Native language & Turkish & 211 & 54.5 \\
& Other & 6 & 1.6 \\
\hline \multirow{2}{*}{ Belief } & Sunni & 327 & 86.5 \\
& Other & 51 & 13.5 \\
\hline & One language & 133 & 34.4 \\
Number of languages used in social relations & Two languages & 154 & 39.8 \\
& Multiple languages & 100 & 25.8 \\
\hline & Province & 221 & 57.3 \\
The settlement where they spend most of their life & District & 114 & 29.5 \\
& Village & 51 & 13.2 \\
\hline Whether they lived in a place with different cultural & Yes & 219 & 56.6 \\
properties in Turkey & No & 168 & 43.4 \\
\hline Whether they have a close friend with different cultural & Yes & No & 338 \\
\hline
\end{tabular}

According to Table 1, 65.5\% of the participants were Kurds-Zazas in ethnic origin while $29.8 \%$ were Turks. $43.9 \%$ spoke Kurdish-Zazaish as their native language whereas 
$54.5 \%$ spoke Turkish. $86.5 \%$ of the prospective teachers participating in the research had Sunni belief while $13.5 \%$ adopted a belief other than Sunni. While 34.4\% used one language in their social relations, $39.8 \%$ used two languages and $25.8 \%$ used multiple languages.57.3\% spent most of their life in a province, $29.5 \%$ in a district, and $13.2 \%$ in a village. Of the participants $56.6 \%$ lived in a place having different cultural properties, $43.4 \%$ lived in a place like the one they lived in. Besides, $87.6 \%$ of the participants had a friend with different cultural properties whereas $12.4 \%$ did not have such a friend.

\section{Data Collection Tool}

Intercultural Sensitivity Scale (ISS) developed by Chen and Starosta (2000), and adapted into Turkish by Üstün (2011) was used as the tool of data collection in this study. The scale in its original form was a 5-pointed Likert type scale containing 24 items and 5 subfactors called interaction engagement, respect of cultural differences, interaction confidence, interaction enjoyment, and interaction attentiveness. The scale was used in this study in onefactor form as it was adapted by Üstün (2011). However, intercultural sensitivity intended to be measured by ISS is a property which can change from culture to culture. Therefore, a new exploratory factor analysis (EFA) was performed in relation to the construct validity of ISS. According to the results of EFA, KMO was found to be 0.90 , and Barlett's test result was found to be significant $(\mathrm{p}<0.05)$. All these results demonstrate that the data collected fit our purpose. According to EFA, the structure of 23-item and one-factor form of ISS was confirmed in this study as in Üstün (2011). It was found that the factor loads for the items in this structure are between .33 and .71. ISS in this form explains $31 \%$ of the variance of the property to be measured. Since the explained variance should be at least $30 \%$ for one-factor scales, this proportion may be said to be adequate. Cronbach's alpha reliability coefficient found in this study was 0.89 . This value indicates that the measurements performed through ISS are highly reliable (Büyüköztürk 2010).

\section{Data Analysis}

The data collected in this study- which examined prospective primary school teachers' levels of intercultural sensitivity according to a number of variables- were analyzed through SPSS 21.0 statistical package. The skewness coefficient for the data was checked and thus whether or not the data had normal distribution was examined, and skewness coefficient was found as -.734. Büyüköztürk points out that data have normal distribution if skewness coefficient is at the +-1 interval (2010: 40). Thus, it may be said that the data collected have normal distribution. Therefore, independent sample t-test and one way Anova- which were parametric tests- were used in the analysis of the data for unrelated samples. Scheffe test, which could be preferred when the sub-unit frequencies constituting the sample were not equal and when the number of sub-units is 3 or bigger (Kayri 2009), was preferred in testing between which groups of two there were significant differences which were found in one-way variance analysis. Eta square values were calculated in order to find the effect values for the variables and the values obtained were interpreted according to the value intervals $(.01=$ small effect, .06=medium effect, .14=big effect) suggested by Cohen (1988; cited in Pallant 2007).

\section{Findings}

Findings on prospective primary school teachers' levels of intercultural sensitivity are shown below. 


\section{Prospective Primary School Teachers' Levels of Intercultural Sensitivity}

Averages and standard deviations for prospective primary school teachers' levels of intercultural sensitivity are shown in Table 2.

Table 2. Prospective Primary School Teachers' Levels of Intercultural Sensitivity

\begin{tabular}{lll}
\hline & $\mathbf{X}$ & Ss. \\
\hline Levels of intercultural sensitivity & 4.04 & 0.48 \\
\hline
\end{tabular}

According to Table 2, the average for prospective primary school teachers' levels of intercultural sensitivity is 4.04 . The value indicates that prospective primary school teachers perceive intercultural sensitivity at satisfactory levels.

\section{Intercultural Sensitivity and Ethnicity}

Results for one-way variance analysis performed to see whether or not intercultural sensitivity levels differ significantly according to the variable of ethnic origin are shown in Table 3.

Table 3. One-Way Variance Analysis Results for the Variables of Intercultural Sensitivity and Ethnic Origin

\begin{tabular}{lcccccc}
\hline Source of variance & Squares total & Sd & $\begin{array}{c}\text { Squares } \\
\text { average }\end{array}$ & F & p & $\begin{array}{c}\text { Significant } \\
\text { difference }\end{array}$ \\
\hline Intergroup & 3.043 & 2 & 1.522 & 6.826 & .001 & $2-4^{*}$ \\
Intragroup & 84.721 & 380 & .223 & & \\
Total & 87.764 & 382 & & & \\
\hline
\end{tabular}

As is clear from Table 3, prospective primary school teachers' levels of intercultural sensitivity differs significantly according to ethnicity. $[\mathrm{F}(2.380)=6.826, \mathrm{p}<0.05]$. According to the results of Scheffe test, intercultural sensitivity levels of prospective primary school teachers who described themselves as Kurds $(\mathrm{x}=4.10)$ were significantly higher than those who described themselves as Turks $(\mathrm{x}=3.92)$. Eta square calculated for the variable of ethnic origin was .03. The value showed that the effects of the variable on prospective primary school teachers' levels of intercultural sensitivity were low. In addition to that, the average for intercultural sensitivity levels for prospective primary school teachers who described themselves as other ethnic groups was $x=3.95$. Yet, there were no significant differences between this group and the other groups.

\section{Intercultural Sensitivity and Native Language}

The results for one-way variance analysis performed to see whether or not prospective primary school teachers' levels of intercultural sensitivity differ significantly according to native language are shown in Table 4.

Table 4. One-Way Variance Analysis Results for Intercultural Sensitivity and Native Language

\begin{tabular}{lccccc}
\hline $\begin{array}{c}\text { Source of } \\
\text { variance }\end{array}$ & Squares total & Sd & Squares average & F & p \\
\hline Intergroup & .513 & 2 & .256 & .111 & .330 \\
Intragroup & 88.64 & 384 & .231 & & \\
Total & 89.152 & 386 & & \\
\hline
\end{tabular}


Research findings suggested that average intercultural sensitivity score for those who spoke Turkish as their native language was $\mathrm{x}=4.01$; it was $\mathrm{x}=4.09$ for those who spoke Kurdish as their native language and it was $\mathrm{x}=4.06$ for those who spoke other languages (Arabic, Lazuri, etc.) as their native language. Yet, according to Table 3, prospective primary school teachers' levels of intercultural sensitivity do not differ significantly on the basis of native language $[\mathrm{F}(2.384)=1.11, \mathrm{p}>0.05]$.

\section{Intercultural Sensitivity and Belief}

The results for independent sample t-test performed to see whether or not prospective primary school teachers' levels of sensitivity differ significantly according to belief are shown in Table 5.

Table 5. Independent Sample T-Test Results for the Variables of Intercultural Sensitivity And Belief

\begin{tabular}{ccccccc}
\hline Belief & $\mathbf{N}$ & $\boldsymbol{X}$ & $\mathbf{S}$ & $\mathbf{s d}$ & $\mathbf{T}$ & $\mathbf{p}$ \\
\hline Sunni & 327 & 4.03 & .477 & 376 & 1.136 & .164 \\
Others & 51 & 4.13 & .417 & & & \\
\hline
\end{tabular}

According to Table 5, prospective primary school teachers' levels of intercultural sensitivity do not differ significantly $(\mathrm{T}=1.136, \mathrm{p}>0.05)$ according to belief. Therefore, it may be said that belief does not influence prospective primary school teachers' levels of intercultural sensitivity.

\section{Intercultural Sensitivity and the Number of Languages Used in Social Relations}

The results for one-way variance analysis performed to see whether or not prospective primary school teachers' levels of sensitivity differ significantly according to the number of languages used in social relations are shown in Table 6.

Table 6. One-one variance analysis results for the variables of intercultural sensitivity and the number of languages used in social relations

\begin{tabular}{|c|c|c|c|c|c|c|}
\hline $\begin{array}{l}\begin{array}{l}\text { Source } \\
\text { variance }\end{array} \\
\text { of }\end{array}$ & Square Total & Sd & $\begin{array}{l}\text { Squares } \\
\text { Average }\end{array}$ & $\mathbf{F}$ & $\mathbf{p}$ & $\begin{array}{l}\text { Significant } \\
\text { Difference }\end{array}$ \\
\hline Intergroup & 3,188 & 2 & 1,594 & 7,121 & ,001 & $1-2$ \\
\hline Intragroup & 85,964 & 384 & ,224 & & & $1-3^{*}$ \\
\hline Total & 89,152 & 386 & & & & \\
\hline
\end{tabular}

*1: one language, 2: two languages, 3: multiple languages

According to Table 6, prospective primary school teachers' levels of intercultural sensitivity differ significantly on the basis of the number of languages used in social relations $[\mathrm{F}(2.384)=7.121, \mathrm{p}<0.05]$. The results coming from Scheffe Test showed that the intercultural sensitivity levels of prospective primary school teachers who were multilingual (x: 4.12) and bilingual (x: 4.10) in their social interaction were significantly higher than those who were monolingual (x: 3.92) in their social interaction. Eta square calculated for the number of languages used in social interaction was .04. The value demonstrates that the relevant variable has low effects on prospective teachers' levels of intercultural sensitivity.

\section{Life}

\section{Intercultural Sensitivity and the Settlement Where They Spend Most of Their}

The results for one-way variance analysis performed to see whether or not prospective primary school teachers' levels of sensitivity differ significantly according to the settlement where they spend most of their life are shown in Table 7. 
Table 7. One-One Variance Analysis Results for the Variables of Intercultural Sensitivity and The Place Where They Spend Most of Their Life

\begin{tabular}{|c|c|c|c|c|c|c|}
\hline $\begin{array}{l}\text { Source } \\
\text { variance }\end{array}$ & $\begin{array}{l}\text { Squares } \\
\text { total }\end{array}$ & Sd & $\begin{array}{l}\text { Squares } \\
\text { average }\end{array}$ & $\mathbf{F}$ & $\mathbf{p}$ & $\begin{array}{l}\text { Significant } \\
\text { difference }\end{array}$ \\
\hline Intergroup & 1.291 & 3 & .645 & 2.81 & .061 & - \\
\hline Intragroup & 87.679 & 383 & .229 & & & \\
\hline Total & 88.970 & 385 & & & & \\
\hline
\end{tabular}

As is clear from Table 7, prospective primary school teachers' levels of intercultural sensitivity do not differ significantly according to the settlement where they spend most of their life $[\mathrm{F}(3.383)=2.81, \mathrm{p}>0.05]$. While the intercultural sensitivity level of the participants who have spent most of their life in a province is $\mathrm{x}: 4.09$ on average, it is $\mathrm{x}: 3.98$ on average for those who have spent most of their life in a district or a village.

\section{in Turkey \\ Intercultural Sensitivity and Lived in A Place with Different Cultural Properties}

The results for independent sample t-test performed to see whether or not prospective primary school teachers' levels of sensitivity differ significantly according to having been to a place of different cultural properties in Turkey are shown in Table 8.

Table 8. Independent Sample T-Test Results for the Variables of Lived in A Place with Different Cultural Properties in Turkey

\begin{tabular}{lllllll}
\hline $\begin{array}{l}\text { Lived in a place with different cultural } \\
\text { properties in Turkey }\end{array}$ & $\mathbf{N}$ & $\boldsymbol{X}$ & $\mathbf{S}$ & $\mathbf{s d}$ & $\mathbf{T}$ & $\mathbf{p}$ \\
\hline Yes & 219 & 4.11 & .467 & 385 & 3.29 & .001 \\
No & 168 & 3.95 & .482 & & & \\
\hline
\end{tabular}

As is clear from Table 8, prospective primary school teachers' levels of intercultural sensitivity differ significantly according to the variable of having been to a place of different cultural properties in Turkey $(\mathrm{T}=3.29, \mathrm{p}<0.05)$. Accordingly, intercultural sensitivity levels of prospective primary school teachers $(X=4.11)$ who have been to a place of different cultural properties are significantly higher than those who have not been to such a place $(X=3.95)$.Eta square calculated for the variable of having been to a place of different cultural properties is .03. The value shows that the variable has low effects on prospective primary school teachers' levels of intercultural sensitivity.

\section{Intercultural Sensitivity and Having a Friend who is Culturally Different}

The results for independent sample t-test performed to see whether or not prospective primary school teachers' levels of sensitivity differ significantly according to a friend of Turkish nationality who is culturally different are shown in Table 9.

Table 9. Independent Sample T-Test Results For The Variables Of Intercultural Sensitivity And Having A Friend Of Turkish Nationality Who Is Culturally Different

\begin{tabular}{lllllll}
\hline $\begin{array}{l}\text { Having a close friend of Turkish } \\
\text { nationality who is culturally different }\end{array}$ & $\mathbf{N}$ & $\mathbf{X}$ & $\mathbf{S}$ & sd & $\mathbf{T}$ & $\mathbf{p}$ \\
\hline Yes & 338 & 4.07 & .484 & 384 & 2.77 & .006 \\
No & 48 & 3.87 & .411 & & & \\
\hline
\end{tabular}

According to Table 9, prospective primary school teachers' levels of intercultural sensitivity differ significantly according to the variable of having a close friend of Turkish 
nationality who is culturally different $(\mathrm{T}=2.77, \mathrm{p}<0.05)$. Accordingly, intercultural sensitivity levels of prospective primary school teachers who have a close friend of Turkish nationality who are culturally different from them $(X=4.07)$ are significantly higher than those who did not have such a friend $(\mathrm{X}=3.87)$. Eta square calculated for the variable of having a friend of Turkish nationality who is culturally different was .02. The value indicates that the variable has low effects on prospective primary school teachers' levels of intercultural sensitivity.

\section{Discussion and Conclusion}

This study analyzed prospective primary school teachers' levels of intercultural sensitivity according to a number of cultural variables. Based on the results obtained, it may be said that prospective primary school teachers are at satisfactory levels in terms of intercultural sensitivity. A study conducted in Greek also demonstrated that prospective primary school teachers had high levels of intercultural sensitivity (Spinthourakis, KaratziaStavlioti, and Roussakis 2009). Another study performed in China, on the other hand, concluded that teachers had low levels of intercultural sensitivity developmentally (Yuen and Grossman 2009). Yuen and Grossmann attributed this result to the fact that individual identities were not prioritized in China. However, as Rengi and Polat (2014) state, it is a desired, ideal situation in terms of educational conception in Turkey-where individual identities are prioritized- for prospective teachers to have a good level of intercultural sensitivity. This situation also indicates that there is no need to be worried about the fact that prospective primary school teachers' probable low levels of intercultural sensitivity can prohibit students from displaying their potentials. The results obtained in this study are reflective of only prospective primary school teachers' perceptions about their intercultural sensitivity. Yet, various studies demonstrate that there can be differences between participants' perceptions of their levels of intercultural sensitivity and the real levels of intercultural sensitivity. The difference shows that the actual levels of intercultural sensitivity may be at least one degree lower than the perceived levels of intercultural sensitivity (Medina-Lopez-Portillo 2004). This finding indicates that prospective primary school teachers' actual levels of intercultural sensitivity may be lower than the levels found in this study.

The research conducted by KONDA (2006) found that the idea of supporting religious and ethnic groups is confirmed the least by Turks. This situation is indicative of the fact that ethnic origin might have an impact on intercultural sensitivity levels. Thus, it was found in this study that the prospective primary school teachers who described themselves as Kurds had higher levels of intercultural sensitivity than those who described themselves as Turks. It is believed that this finding has to do with the multicultural properties of south eastern region of Turkey-where Kurds live intensely- which the region has distinctively (Kaya 2007). The finding can also be explained with dominant and non-dominant cultural properties because individuals with dominant cultural properties can display lower levels of intercultural sensitivity developmentally (Hammer, Bennett, and Wiseman 2003). However, it cannot be said that the situation is always true in all contexts; because even though having or not having dominant ethnic properties has significant effects on the levels of intercultural sensitivity according to the research findings, the same effects were not observed in terms of belief. Although the intercultural sensitivity levels of the participants who described themselves as Alewis, Agnostics, Atheists and Deists were higher than those who described themselves as Sunni Muslims; the difference was not found to be significant.

Rengi and Polat (2014) found that prospective primary school teachers perceived "linguistic differences" most as cultural differences. Considering the fact that the level of intercultural sensitivity will rise in parallel to awareness of intercultural differences and in 
parallel to distinguishing between those differences (Bennett 2004), it is expected that native language has significant effects on individuals' levels of intercultural sensitivity. However, it was found in this study that native language did not cause significant differences in participants' levels of intercultural sensitivity.

Although the variable of native language did not have any significant effects on the levels of intercultural sensitivity, the number of languages used in communication with family and relatives was found to have significant effects on the prospective primary school teachers' levels of intercultural sensitivity. Thus, intercultural sensitivity levels of prospective primary school teachers using two or more languages in communication with their family members or relatives were significantly higher than those using one language. Based on this fact, it may be said that the factor influencing intercultural sensitivity is not the differentiation in the language used. The main variable influencing intercultural sensitivity is the number of different languages used- or the number of languages with which one has experience. In support of this view, various studies found that if an individual spoke a language apart from his/her native language or if he/she learnt or spoke a foreign language, it increased intercultural sensitivity levels (Bekiroğlu and Balc1 2014; Engle and Engle 2004). Yet, what is meant by the term foreign language in those studies is a language spoken in a foreign country. But this current study demonstrated that experiencing with different languages spoken in one's own country would also increase intercultural sensitivity.

Studies analyzing the effects of the settlement on the level of intercultural sensitivity demonstrated that this variable was influential in intercultural sensitivity. Yılmaz and Göçen (2013) found that prospective teachers' levels of intercultural sensitivity rose in parallel to the increase in the size, development and population intensity of a settlement. Üstün (2011), in a similar way, concluded that the prospective teachers who had grown up in a province had higher levels of intercultural sensitivity than those who had grown up in a small settlement. Pederson (1997), on the other hand, considered the concept of settlement and thus demonstrated that living in suburbs would have positive effects on the levels of intercultural sensitivity. This study, however, as different from those studies, demonstrated that the settlement where prospective primary school teachers had spent most of their life did not have significant effects on their intercultural sensitivity levels.

A number of studies demonstrated that experience of living abroad for various reasons (Altshuler, Sussman, and Kachur 2003; Bhawuk and Brislin 1992; Clarke et al. 2009; Pedersen 2010; Westrick and Yuen 2007) or having friends from a different country and culture (Baños 2006; Del Villar 2010; Pederson 1997; Üstün 2011) affected intercultural sensitivity levels in a positive way. This study also reached similar conclusions by considering the experience gained through living in different cultural environments and intercultural friendship in the context of cultural differences in one's own country. Accordingly, it was found that prospective primary school teachers who had experience of living in a place of different cultural properties in Turkey were more sensitive in terms of intercultural differences than those who did not have such experience and that prospective primary school teachers who had a close friend of Turkish nationality who was culturally different were more sensitive than those who did not have such a friend.

The problem of this research was based on the fact that prospective primary school teachers as individuals and as teachers would be working mostly in the rural areas of the Eastern and south eastern regions of Turkey even though they had grown up in regions and settlements with different cultural properties. Therefore, the results obtained in this study should be interpreted accordingly. Thus, it may be said that teachers who describe themselves as Turks in ethnicity, who have not had any prior experience with languages spoken in their country by people of different cultural properties, who have not been to places in their country 
where people of different cultures live intensely and who have not had any close relations with those people will encounter more problems in intercultural sensitivity than others. Setting out from the dimensions of intercultural sensitivity (Baños 2006), it can also be said that those prospective teachers may not be able to communicate with parents, students, colleagues and the close neighborhood of the school having different cultures in the places where are appointed to work; and that they may not enjoy the situation, they may be careless, they may feel insecure in communication or they may be disrespectful to cultural differences even if they can communicate with them. Considering the fact that the labor productivity and job satisfaction of people experiencing problems in intercultural sensitivity will decrease (Sizoo et al. 2005), it can be said that such prospective teachers may not attain the desired success while working in regions of different cultures. However, it should be stated that all these stem from prospective teachers' lack of intercultural sensitivity levels which would facilitate their experience with intercultural differences and not from being good or bad (Bennett 2004).

\section{Limitations and Recommendations}

The statements used this study in relation to the cultural differences in the data collection tool indicate cultural differences in general sense, and not the differences in belief or language of a certain ethnic group. The results were assessed in a special context- in the context of cultural differences in the eastern and south eastern regions of Turkey. This situation may be considered as a restriction for the study. Setting out from this, an intercultural sensitivity scale referring to cultural differences of national scale in Turkey could be developed in the future and this study could be repeated for the same purpose. In this way, whether or not prospective primary school teachers are sensitive to cultural differences in their own country can be more clearly demonstrated.

This study was conducted with prospective primary school teachers trained in two universities one of which was in the Marmara region and the other of which was in the south eastern region of Turkey. Therefore, data enough to be included in analysis of each category determined especially for belief were not collected. For this reason, it is thought that intercultural sensitivity should be considered according to different beliefs apart from Muslim Sunni belief by collecting data from the seven regions of Turkey. Such an approach of sampling could enable researchers to research the effects of culturally different regions on intercultural sensitivity.

The basic inference made from this research is that intercultural sensitivity is influenced by experiences with cultural differences rather than by cultural differences. Therefore, teacher training programs should firstly aim to raise teachers who can have intercultural communication, who will enjoy this, who will be careful about this, who will be self-confident and who will respect differences. Educational experiences to enhance prospective teachers' cultural interaction should be available to attain this goal. The multicultural structure of universities should be used for this purpose. Emphasis should be laid on the intercultural differences of prospective primary school teachers who have taken such courses sociology which is concerned with culture and cultural differences and Teaching Life Sciences and Teaching Social Studies (Yetkin and Daşcan, 2010) which consider respecting individual differences as a student gain; and those differences should be discussed in an environment of freedom. Besides, according to the findings obtained in the research, having lived in a place with different cultural characteristics and having friends with different cultural characteristics affect the intercultural sensitivity levels of candidates of primary school teacher. In this regard, in the "Community Service Applications Course" in the primary school teaching department undergraduate program, projects where candidates of primary school teachers having culturally different characteristics will work in collaboration 
in culturally different places should be realized. In this way, it should be ensured that they obtain experiences related to cultural differences. Compulsory courses directly considering the ethnic, religious and belief differences should be added to the primary school teacher training programs. One-semester internship program for newly appointed teachers- which has just started in Turkey- should be applied in regions where prospective teachers are appointed, not in their hometown, and the program should contain experiences to help those teachers adopt perspectives about the cultural differences in those regions in addition to professional experience. Apart from that, prospective teachers representing the dominant culture especially could be recommended to make efforts to exist in culturally different environments with their moral identity which means internalizing the moral values (Y1lmaz and Y1lmaz 2015) not with their ethnic or religious identity. As is apparent from the studies, individuals' levels of intercultural sensitivity do not develop only by being exposed to multicultural environments (Bayles 2009). Therefore, teachers and prospective teachers could be recommended to try to learn and experience the experienceable differences such as the languages of those cultures in environments of different cultures.

\section{References}

Altshuler, L., N., Sussman, N. M., \& Kachur, E. (2003). Assessing changes in intercultural sensitivity among physician trainees using the intercultural development inventory. International Journal of Intercultural Relation, 27, 387-401.

Anderson, P. H., Lawton, L., Rexeisen, R. J., \& Hubbard, A. C. (2006). short-term study abroad and intercultural sensitivity: A pilot study. International Journal of Intercultural Relations, 30, 457-469.

Baños, R. V. (2006). Intercultural sensitivity of teenagers: a study of educational necessities in Catalonia. Intercultural Communication Studies, 15 (2), 16-22.

Başbay, A. (2014). Investigation of multicultural education courses: The case of Georgia State University. Educational Sciences: Theory and Practice, 14 (2), 585-608.

Bayles, P. P. (2009). Assessing the intercultural sensitivity of elementary teachers in bilingual schools in a texas school district (Doctoral thesis dissertation). Retrieved from University of Minnesota.

Bekiroğlu, O., \& Balcı, S. (2014). Looking for the clues of sensitivity of intercultural communication: A survey on the sample of communication faculty students. Selçuk University Journal of Studies in Turcology, 35, 429-458.

Bennett, J. M., \& Bennett, M. J. (2004). Developing intercultural sensitivity: an integrative approach to global and domestic diversity. In Bennett J. M \& Bennett, J. M. (Eds.) Handbook of Intercultural Training (pp. 147-165). CA: Sage.

Bennett, M. J. (1986). A developmental approach to training for intercultural sensitivity. International Journal of Intercultural Relations 10: 179-195. doi:10.1016/0147-1767(86)90005-2.

Bennett, M. J. (2004). “-Becoming interculturally competent.-" In J. S. Wurzel (Ed.) Toward multiculturalism: A reader in multicultural education, Newton, MA: Intercultural Resource Corporation.

Bhawuk, D. P., \& Brisli, R. (1992). The Measurement of Intercultural Sensitivity Using the Concepts of Individualism and Collectivism." International Journal of Intercultural Relations, 16, 413436.

Büyüköztürk, Ş. (2010). Sosyal bilimler icin veri analizi el kitabı. Ankara: Pegem Akademi.

Büyüköztürk, Ş., Kılıç Çakmak, E., Akgün, Ö. E., Karadeniz, Ş., \& Demirel, F. (2013). Bilimsel araştırma yöntemleri. Ankara: Pegem Akademi. 
Chen, G. M., \& Starosta, W. J.(2000). The development and validation of the intercultural sensitivity scale. Human Communication, 3 (1), 1-15.

Chen, G.-M. (1997). A review of the Concept of Intercultural Sensitivity. Paper presented at the biennial convention of the Pacific and Asian Communication Association. Honolulu, January.

Chen, G.-M. (2010). The impact of intercultural sensitivity on ethnocentrism and intercultural communication apprehension. Intercultural Communication Studies, 19 (1): 1-9.

Chen, G.-M., \& Starosta, .W. (1998-9). A review of the concept of intercultural awareness. Human Communication, 2: 27-54.

Cirık, İ. (2008). Multicultural education and its reflections. Hacettepe University Journal of Education, 34, 27-40

Clarke, I.,. Flaherty, T. B, Wright, N. D., \& McMillen, R. M. (2009). Student intercultural proficiency from study abroad programs. Journal of Marketing Education, 31 (2), 173-181.

Council of Higher Education [Yükseköğretim Kurulu]. (accessed May 12, 2016 ) http://www.yok.gov.tr/.

Del Villar, C. P. (2010). How savvy are we? Towards predicting intercultural sensitivity. Human Communication, 13 (3), 197-215.

Engle, L., \& Engle, J. (2004). Assessing language acquisition and intercultural sensitivity development in relation to study abroad program design. The Interdisciplinary Journal of Study Abroad, 10, 219-236.

Fabregas-Janeiro, M., Kelsey, K. D., \& Robinson, J. S (2011). Assessing changes in intercultural sensitivity among agricultural students exposed to international experiences. Journal of International Agricultural and Extension Education, 18 (1), 34-44.

Fuller, T. L. (2007). Study abroad experiences and intercultural sensitivity among graduate theological students: A preliminary and exploratory investigation. Christian Higher Education, 6 (4), 321 332.

Gay, G. (2002). Preparing for culturally responsive teaching. Journal of Teacher Education, 53, 106116.

Hammer, M. R., Bennet M. J., \& Wiseman, R. (2003). Measuring intercultural sensitivity: The intercultural development inventory. International Journal of Intercultural Relations 27, 421423.

International Minority Rights Group [IMGR]. (2007). "-Bir Eşitlik Arayışı: Türkiye'de Azınlıklar-." $\begin{array}{llll}\text { Accessed } & 09 & \text { January } 2017 . & \mathrm{http} / / / \text { minorityrights.org/wp- }\end{array}$ content/uploads/2015/07/MRG_Rep_Turk2007_TURK.pdf

Karasar, N. (2012). Bilimsel araştırma yöntemleri. Ankara: Nobel Yayınc1lık.

Kaya, İ. (2007). Minorities, multiculturalism and mardin."Dicle University Journal of Ziya Gökalp Education Faculty, 9, 44-55.

Kayri, M. (2009). The multiple comparison (post-hoc) techniques to determine the difference between groups in researches, Firat University Journal of Social Sciences, 19 (1), 51-64.

KONDA. (2006). Toplumsal yapı araştırması. Biz kimiz?. Accessed 24 February 2016. http://www.konda.com.tr/tr/raporlar/2006_09_KONDA_Toplumsal_Yapi.pdf

Medina-Lopez-Portillo, A. (2004). Intercultural learning assessment: The link between program duration and the development of intercultural sensitivity. Frontiers: The Interdisciplinary Journal of Study Abroad, 10, 179-199.

Neuliep, J. W. (2006). Intercultural communication a contextual approach. California: Sage Publications Inc. 
Pallant, J. (2005). SPSS survival manual: A Step by step guide to data analysis using spss for windows. Australia: Australian Copyright.

Pedersen, P. J. (2010). Assessing intercultural effectiveness outcomes in a year-long study abroad program. International Journal of Intercultural Relations, 34, 70-80.

Pederson, P. V. (1997). Intercultural sensitivity and the early adolescent. Paper presented at the annual meeting of the National Council for the Social Studies, Cincinnati, Novermber 20.

Peng, S.-Y. (2006). A comparative perspective of intercultural sensitivity between college students and multinational employees in china. Multicultural Perspectives, 8 (3), 38-45.

Perry, L. B., \& Southwell L. (2011). Developing intercultural understanding and skills: Models and approaches. Intercultural education, 22 (6), 469-482.

Polat, İ., \& Kılıç, E. (2013). Multıcultural education in turkey and teachers' competencies in multicultural education. Yüzüncü Yll University Journal of Education Faculty, 10 (1), 352372.

Rengi, O., \& Polat, S. (2014). Primary teachers' perception of cultural diversity and intercultural sensitivity. Journal of World of Turks, 6 (3), 135-156.

Sizoo, S., Plank, R., Iskat W., \& Serrie, H. (2005). The effect of intercultural sensitivity on employee performance in cross-cultural service encounters. The Journal of Services Marketing, 19 (4), $245-255$.

Spinthourakis, J., Karatzia-Stavlioti E., \& Roussakis, Y. (2009). Pre-service teacher intercultural sensitivity assessment as a basis for addressing multiculturalism. Intercultural Education, 20 (3), 267-276.

Straffon, D. A. (2003). Assessing the intercultural sensitivity of high school students attending an international school. International Journal of Intercultural Relations, 27, 487-501.

Şahin, İ., F., \& Ekici, Ö. (2019). Sosyal bilgiler öğretmenlerinin perspektifinde ortaokullarda vatandaşlik eğitiminde yaşanan sorunlar. Journal of History School, 19, 85- 116.

Üstün, E. (2011). Factors Affecting Teacher Candidates' Intercultural Sensitivity and Ethnocentrism Levels (Master dissertation), Retrieved from Y1ldız Technical Unıversity, İstanbul.

Westrick, J. M., \& Yuen, C. Y. (2007). The intercultural sensitivity of secondary teachers in Hong Kong: A comparative study with implications for professional development. Intercultural Education, 18 (2), 129-145.

Williams, T. R. (2005). Exploring the impact of study abroad on students' intercultural communication skills: adaptability and sensitivity. Journal of Studies in International Education, 9 (4), 356-371.

Yetkin, D., \& Daşcan, Ö. (2010). İlköğretim programı: 1-5. sinıflar. Ankara: Anı Yayıncılık.

Y1lmaz, F., \& Y1lmaz, F. (2015). The validity and reliability study of moral identity scale's turkish version. Celal Bayar University Journal of Social Sciences, 13 (4), 111-134.

Yılmaz, F., \& Göçen, S. (2013). İnvestigation of the prospective primary teachers' intercultural sensitivity levels in terms of certain variables. Journal of Social Sciences Institute of Adlyaman University, 6 (15), 373- 392.

Yuen, C. Y., \& Grossman, D. (2009). The intercultural sensitivity of student teachers in three cities. Compare: A Journal of Comparative and International Education, 39 (3), 349-365. 